\title{
Transitional Religiosity: The Religion of Generation $\mathrm{Z}$
}

\author{
Leonard Chrysostomos Epafras ${ }^{1}$, Hendrikus Paulus Kaunang ${ }^{2}$, Maksimilianus Jemali ${ }^{3}$, \\ Vania Sharleen Setyono ${ }^{4}$ \\ \{leonard_epafras@staff.ukdw.ac.id ${ }^{1}$, erichkaunang@ugm.ac.id ${ }^{2}$, lianjemali28@gmail.com³ \\ vaniasharleen@staff.ukdw.ac.id $\left.{ }^{4}\right\}$
}

Universitas Kristen Duta Wacana, Yogyakarta ${ }^{1}$, Universitas Gadjah Mada, Yogyakarta ${ }^{2}$, Universitas Katolik Indonesia Santu Paulus, Ruteng ${ }^{3}$, Universitas Kristen Duta Wacana ${ }^{4}$

\begin{abstract}
The present paper is the outcome of three-months research in 2019 on the religiosities of the Indonesian Generation Z (Gen Z). The two research questions oriented this undertaking, first, how is the formation of Gen $Z$ religiosities within the context of communicative abundance? Secondly, how do they strategize the social media for their religiosities in the transitional phase to adulthood? We conducted seventy-five interviews and Focus Group Discussions and 745 respondents in an online survey, among the twelfth grade of senior high schoolers, and the first to third year of university students. The outcome of the research indicated among others, the prominent of Millennials' position as the new religious authority and information curators for Gen Z; their distinct maneuver in social space; the formation of homophilial religious governmentality; and their negotiation and resistance toward certain religious doctrines.
\end{abstract}

Keywords: Generation Z, religion online, religious subjectivity, youth religiosity, religion in Indonesia.

\section{Introduction}

As argued by many, young people are a critical generation for any community as to them the next shoulder of leadership is relying on and the future of a nation is ensured. Some enthusiastically take them as the spearhead of global consumption, as a "new powerhouse" [18]. The energy and attention given to them does not necessarily come from a balanced view of this generation, however.

Though not entirely unwarranted, in many ways they became "object," "target," and treated as less autonomous subjectivity. They are discursively called "generasi penerus" (the next generation), rather than "generasi penentu" (self-determined generation). They need to be "protected" from many global perils such as consumerism, religious radicalism, gaming subculture, smartphone/gadget addiction, suffering a Peter Pan complex, "they don't want ever to grow up" [1] and on the other hand, became a strategic market, ranging from consumer goods to religious ideologies. Young people became and are a fertile field of religious mission and $d a^{\prime} w a$ since a long period of time. Along with this observation, we found numerous studies about the youngster's consumption pattern [19], but also the exposure of the youngsters toward religious radicalism [2]. The "vulnerability" of the young people became the main concern of the adults, which might have clouded the judgment of their subjectivity.

Gen $\mathrm{Z}$ is becoming the main target of those initiatives that seemingly a straightforward economical and religious motive in fact revealed the larger complicated condition. Firstly, it is 
a reflection of intergenerational tension in which Gen $\mathrm{Z}$ is judged through their difference against the earlier generation in terms of taste, capacity, orientation, and social preference. Secondly, it is an example of adult gaze that objectified the Gen $\mathrm{Z}$ agency and experience.

The present research is a way to learn the subjectivity of the Indonesian Gen Z. This study is conducted in part to understand their religious formation in social media (socmed). Socmed in this regard is considered as the outcome of the modernity condition of communicative abundance [10]. Indonesian Gen $\mathrm{Z}$ is living in the days where telecommunication operators became among the most powerful economic agencies, hence ushered further to the condition of communicative abundance. It has appeared along the growing pro-market government policy during the tenure of President Jokowi who invested millions of dollars to stimulate the millennials-driven market. It further presumed that in their liminal state, they underwent a stage (or series) of micro-conversion within their respected religion, transformation for (or against) religions, finding and despising religion.

Hence, the title of the project "Transitional Religiosity" might give a sense of impermanence of Gen $\mathrm{Z}$ religious position and multiple trajectories of their future to come to term with adulthood. "Transitional" could also lead to the harden religious position. Many observations indicated the increasing conservatism among the youths, which appeared in terms of communalism and scripturalism [2]. On the other hand, those were perceived as a sanctuary, a safe haven for Muslim youths from the frenetic of the world [9]. We further argued that in the Indonesian context, there are more complex social arrangements, notably among the aggregation of traditional, modern, urban, semi-urban, and countryside societies. Regardless of the shift from traditional religious authority, it remains potent for many Indonesian youths. It appeared in multiple faces, from the new authority (e.g., digital friendly preacher and leaderships) to the structure that attempted to transform, recast, and redefine itself, to be more relevant to the wind of change.

The entire activity oriented by two basic questions, i.e. (1) how is the formation of Gen Z religiosity within the context of social media? Moreover, (2) how do they strategize social media for the above purpose in the transitional phase to adulthood?

The findings of the research indicated five insights, outlined as follows:

First, we testified the ever growing and prominent position of the Millennials as new religious authority and information curators for Gen Z. Secondly, Gen Z exercised religious independence and flexibility against the family upbringing through engagement with peers and socmed.

Thirdly, student's religious bodies and communities such as UKM (Unit Kerohanian Mahasiswa), PMK (Persekutuan Mahasiswa Kristen), halaqa/liqa', komsel (cell groups) and others became the site of nurturing homophily's student groups that endorsed specific religious aspirations, through which religious governmentality is also implied. In many ways the religious ideology tended to be less concerned with other religions, or simply intolerant toward the religious differences.

Furthermore, Gen $\mathrm{Z}$ consumption of religious messages is very much visual-based -- and in many ways marked the return of secondary orality -- hence limited to the more intellectual affirmation mode of expression induced mainly by traditional religious discourse. Socmed outlets such as YouTube, Instagram, and in particular TikTok instrumental in this process. No more Facebooks and Twitters!

Eventually, in terms of religious representation in socmed, minority groups of Buddhist, Confucian and spiritual communities remained marginal, enforcing the adage "minority offline, minority online." 
The present paper addresses four of the above findings in the following parts, i.e., the position of the Millennials, the independent but governmentalized religious selves, visual culture as the Gen $\mathrm{Z}$ religious expression, and young religious minority experience. Other issues such as Gen $\mathrm{Z}$ experience in religio-political polarization is not addressed in the present paper.

Admittedly, there were at least two limitations of this research:

First, the research encountered difficulties to mobilize the balanced informer's population for interviews, such as Buddhists, Confucianists and other minority groups could not be properly represented. The period of data gathering was unfortunately coincided with the inter session period in which many of the students were returned to their hometowns.

Second, in terms of online survey, more than sixty percent of the respondents were female youngsters, i.e., $65 \%$ against $35 \%$. It indeed may limit the claim of the general Gen Z religiosity. Nevertheless, when the religious self-perception breaks down to sex categories, the result is almost identical, as Figure 3 and Figure 4 informed, as against Figure 2 for the overall observation. Those limitations however, still brought a representative insight into the analysis.

\section{Theoretical Framework and Methods}

Drew from the earlier research, notably Epafras [5] that focused on the Millennials, the present research is to a certain extent an extended concern from it, but also a way to understand further in which the digital realm became the channel of religiosity.

In the aforementioned work, Epafras informed the complexity of presentation of the Millennials in regards on religious issue, as it can be summarized as follows: (1) Internet became the space of the expression of masculinity and the projection of masculinity imagination; (2) Internet is a space for social engagement, oftentimes in a fun way and maintain the interfaith tone; (3) Internet is a place for the youth political exercise as the case of Teman Ahok and many gadget application productions to support the general election of 2014; (4) Youth engaging expression of religious issues appeared with strong youth culture, but oftentimes they became the mouthpiece of religious conservatism, which limited the meaningful interaction with other religious groups; (5) Commodification of religious experience or the primacy of affectionate politics become the preference of the youths against the rational affirmation religious presentation.

In the present undertaking, the research team focused on the subsequent generation of Gen $Z$. They focus no more on the presentation of religiosity of the youngsters in the digital realm but move further for the understanding of religious formation in the transitory context.

The hypothesis is that Gen $\mathrm{Z}$ underwent the beginning of the process of transitional religiosity, in which there would be displayed to at least one or more conversion and "microconversion" experiences. This is presumably facilitated by the nature of their interaction with their peers, parents (or caregivers), and gadgets. The groundbreaking work of Victor Turner on rites of passage, which drew inspiration from Arnold van Gennep [22] became the basic theoretical framework in understanding the above phenomenon. Rite of passage provided the youth a condition of ambiguity and confusion as they moved from the earlier state (communitas) and entered transitional phase (liminality) before coming to "reaggregation and incorporation" of a new "stability", a new communitas [21].

In the present research we argued further that beyond the average community setting and arrangement, the present-day youngsters have a multiple strand of self-formation beyond the more static Gennep-Turnerian model. Biological rite of passage is natural and fixed, except in some random cases, that is understood within the culture and social upbringing. However, 
there are numerous social rites of passage, including the religious one, such as hajj, conversion, baptism, and circumcision that are also formative for people's process of individualization and socialization.

In the digital realm, the visual imaginary and multiple sensuality produced through the bombardment of information, visualization, video, and others, somehow affected the transitional process of knowledge formation, hence to the liminality stage. Those might be affected by certain religious and social imagination that encourage for certain action and religious commitment. Hijra, growing (bertumbuh), reevangelisasi (reevangelization), are the new lingo of micro-conversion and rites of passage within the religious discourse in the digitalized social interaction $[2,20,11]$. This might have created the "transitional" state as the aforementioned insights. Against those conditions, Gen $\mathrm{Z}$ are still in the stage of rightsizing their identity and have undergone numerous identity crises and are facing an undetermined future [cf. 7].

In Islamic discourse, youth, as claimed by Hasan, became the "entrepôts in the flow of revivalist Islamic messages and ideas, and act as transmitters who creatively translate those messages into lifestyles, fashion, arts, music, novels, books, institutions, and organizations" [6]. "Transitional" could also turn to the hardened religious position. Another observation indicated the increasing conservatism among the youths, which appeared in terms of communalism and scripturalism [2]. On the other hand, those were perceived as a sanctuary, a safe haven for Muslim youths from the frenetic of the world [9].

The "transitional" state is not only embracing the religionists. Earlier research of Epafras [5] detected the presence of non-religious affiliation, or the "nones." In large part nonaffiliated is still a socially unacceptable position in Indonesian public conversation. According to Pew Research Center 2015's survey, 35\% of American millennials tick "nones" or "nothing in particular" or reject religious labels [12].

The category of "None," an abbreviation of the "none of the above" refers to the survey of religious affiliation in which the informer does not display any affiliation with the existing religious categories [14]. The gamut embraced by this category includes irreligiosity [3], "atheism," "agnosticism," and "spiritual/religious anarchism" in general. Those would give a balance to the earlier description of religious radicalization among the youths. It might give a sense of possibility of (ir-)religious transitional experience as well.

The Millennials and Gen Z, both exposed to digital technology in the sense that it became their secondary orality. Secondary orality is

"both remarkably like and remarkably unlike primary orality. Like primary orality, secondary orality has generated a strong group sense, for listening to spoken words forms hearers into a group, a true audience, just as reading written or printed texts turns individuals into themselves. But secondary orality generates a sense for groups immeasurably larger than those of primary oral culture - McLuhan's 'global village'” [17].

Their sense of "social" evolved with their technologized language protocol, which in the present day realized in social media technology. Primary orality dealing with "speak" and arguably closer to human existence and its connection with "the sacred" [17]. Secondary orality and within the context of digital technology is unlike the primary orality that produces events of face-to-face interaction, it mediated heavily by digital protocols and mediatization, and it furthermore combined with visual and textual culture. It transforms the "speak" into more complex and polimediatic interaction, but retains the effect of sociality and temporality, as it is an "instrumentalized" speaking. It is, furthermore, broadens the sense of social (groupminded) as the symbolic landscape of interaction and as an expansion beyond traditional 
spatial restriction. But it is also more programmatic and vulnerable to restricted social grouping, hence complicated the meaning of civic engagement in this transitory state [cf. 17]. This condition in many ways manifested in collective action, polarized social interaction and the engagement with religious homophily's communities, as appeared in the involvement of Gen $\mathrm{Z}$ and the Millennials in Indonesia Tanpa Pacaran campaign [20].

Still, Gen $Z$ is living at the end of the process of communicative abundance, a critical concept endorsed by an Australian political scientist, John Keane. Communicative abundance is

"centred on text, touch, sound and image, ... [it] draws together and stimulates most human senses ... And it involves a second combination: in some circumstances (reading a novel or newspaper on a tablet) the new mode of communication fosters reflective detachment, whereas in other settings (using Skype or messaging a friend on the other side of the planet, or wearing smart glasses) it requires the deep participation of its users and stimulates their various senses, in different combinations" [10].

This is not only an explanation of the more and more intense screen time for average people, but it may explain the condition such as new habit of involving many activities beyond mere "communicating," such as online transportation dependence, tapping the e-money card for transaction, GoPay for church offering, QR scanning for registering to a conference, and so on, which the dynamic of attachment/detachment is prominent.

It is at this juncture, despite the high capacity of experimentation among the youngsters, the communicative abundant became the huge temptation to clamp their lives [10]. However, at this very point, understanding the religious formation of the youngsters is important. We argued that in the Indonesian context, there are more complex social arrangements, notably among the aggregation of traditional, modern, urban, semi-urban, and countryside societies. Regardless the shift of religious authority, in particular affected to the traditional structure, "authority" remains potent and appeared in multiple faces, from the new authority (e.g., digital friendly preacher and leaderships) to the structure that attempted to transform, recast, and redefine itself, to be more relevant to the wind of change.

The research activity was conducted between May - October 2019 focusing on the high school students (grade twelve) and university students from the first to the third year of study (16-28 years old). In some ways, it overlapped with "junior millennials" as other research included the age 21-28 years into their considerations [8]. Four of the informers were Millennials (26-28 years old) as they provided comparative insights to our discussion. We interviewed seventy-seven twelfth grade high school and university students in personal and focus group discussions, from all six recognized religions, plus one group represented a spiritual group (aliran kepercayaan), and non-religiously affiliated individuals, in Yogyakarta, Manado, Medan, and online (Figure 1). We further gathered 745 respondent's opinions through an online survey focusing only on the university students which represented twelve provinces and thirty higher education institutions throughout the country.

\section{Research Findings}

\subsection{The Millennials: Information Curator and New Religious Authority}

In the context of the shift of religious authority, Millennials in many cases became the role model for Gen Z. Millennial's public figures such as Reza “Arap” Oktovian, Hanan Attaki, 
Cania Citta Irlanie, Christofer Tapiheru, Banthe Dhirapuñño, Gus Milenial, Ustazah Mumpuni Handayayekti and others, with hundreds of thousands to millions of followers in the socmed, have become new reference for this generation, for some even, a new religious authority. They became the information and knowledge curator for the youth targeted market. Three ministers and seven special presidential aides in the new administration of Jokowi giving more gravity to our observation.

Information curator is the agency that supports, manages, organizes, selects, promotes, and controls, information and socmed content for the socmed figures (selebgram, micro-ustadz, micro-preachers, and so on) and also socmed followers. The process is included to the level of presentation and repackaging it. This function allowed the agency to endorse certain positions, be it ideological, commercial or religious, and frame it for certain purposes.

The curated information however in the context of communicative abundance is not thoroughly hegemonic. This context is marked with the huge proliferation of information channels and outlets, in which Gen $Z$ maintain a freedom to choose their sources. Paradoxically, at this point the digital algorithm escorted the religious preferences of Gen $Z$ toward a certain end, manifested for instance, hashtags and the activity of sharing, resharing, tweeting, mentioning, and retweeting. Through this mode of communication, we testified the power of religious rhetoric, as testified in \#IndonesiaTanpaPacaran over the Gen Z conversation.

To the latter as an example, there were paradigm sharing between the "conservative" Christian and Muslim positions on romantic relationship. Both provided extra religious boundary in dealing with the relationship with the opposite sex, let alone in regards of cross-confessional relationship. For instance, both agreed on the anti-dating relationship (tanpa pacaran). However, unlike Islamic context with the massive movement of \#IndonesiaTanpaPacaran and \#IndonesiaTanpaFeminisme, there are no massive movements among the Christian youths, except as a theological idea and ethical advisory. Secondly, the massive usage of scriptural quotations as it offers "eternity" not as an abstract idea but immersed into pop culture and digital culture.

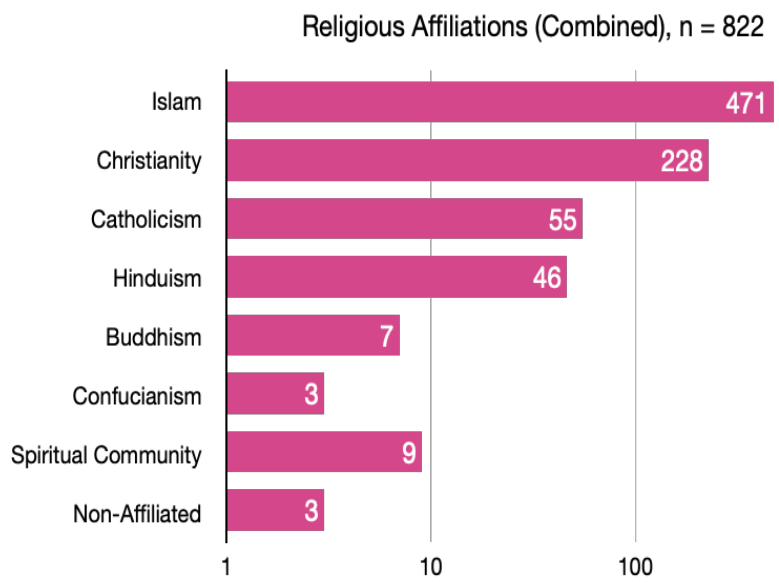


Fig. 1. Informers' religious composition of Gen Z, combined interviews, FGDs, and online survey

\subsection{Independent, Flexible and Governmentalized Religious Selves}

One interesting finding from the survey was that many Gen $Z$ considered themselves moderately religious against their family upbringing. Most of them portrayed their family either religious or very religious. This is not necessarily considering the tendency of becoming less religious in the survey population, or whether religion lost their appeal among the youths. It might be seen as the process of being more flexible on the issue of religiosity, an exercise of their independence and a process of rightsizing with the new social context.

Such flexibility also appeared from the survey that little bit more than half of the respondents $(51 \%)$ agreed to learn other religions beyond her/his religious commitments. $27.5 \%$ are taking "maybe" positions, and $21 \%$ simply unwilling to engage with other religions. Social space is not only about a fixed space of social interaction. It is embracing the condition of maneuvering between spaces and different modes of self-presentation. An example of this condition is displayed by a santriwati (female student at an Islamic boarding school) from Central Java who studied in a pesantren (Islamic boarding school) in Yogyakarta. During the interview she displayed strong leaning to the interfaith interaction endorsed by her pesantren as her new religious experience that contrasted with her earlier more traditional outlook. Regardless of her eloquence on the matter of interfaith, her Instagram account is absent entirely on interfaith issue. Her posted pictures all only about her connection with Islam. This might give a sense of space management through which different modes of self-presentation are exercised.

Understanding this within the larger socio-political context, it might emphasize the complicated interreligious interaction, in particular that is manifested in the socmed in which the presumably violation of religious boundary - in this case, the interfaith engagement might come with unintended digital repercussions.

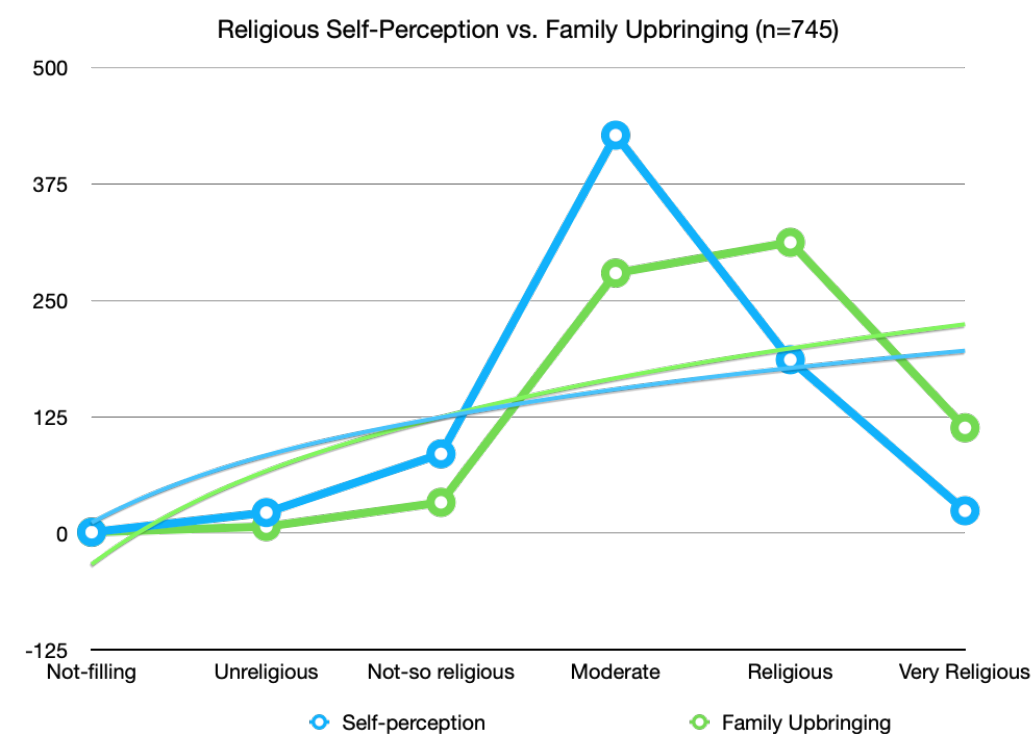


Fig. 2. Online Survey: Gen Z religious self-perception vs. their perception of family religious upbringing among the overall students

Small groups and private public space/public sphericule became the arena of religious formation for Gen Z. In non-confessional universities, UKM (Unit Kerohanian Mahasiswa, Student Religious Body), a formal university-granted student body has to compete with the "private" student organizations and religious body representation such as halaqa/liqa', komsel, PMK (Persekutuan Mahasiswa Kristen, Christian Student Fellowship), and others. This might not be a new phenomenon since such movements have been initiated and have been active since the 1970s. However, the present development gave a more dynamic picture since social media became a crucial element for mobilizing religious lives on campus.

There is a possibility of the formation of a homophilial group that enforced certain religious ideological positions within the similar religious interest and affiliation, through which the seniors of the group oftentimes limit the religious exploration of their juniors. Liqa' or halaqa (study circle) and komsel (komunitas sel, cell groups) is a religious mentoring system, which is popular among the university students, though komsel is also a spiritual development system in some churches, that is a place for religious/spiritual nurture.

Other researches concurred with the possibility of religious indoctrination and nurturing non-accommodative attitude toward other religions within this social arrangement, which in part encroached traditional religious authority [e.g. 4, 13]. The members' exposure to more intolerant religious positions should look as well as other factors and Gen Z subjectivity formation. However, such limited exposure to religious differences might emphasize the vulnerability to such religious intolerance. In an example of a state university komsel community, which the tagline expressed in English is "there is no growth in comfort zone, there is no comfort in growth zone", the main activities are bible study, pray, and life sharing as a means to "grow together in the God's formation process." Furthermore, it strongly endorses missionizing others to "save the lost souls." Missionizing and da'wa are seemingly integral part of their religious identity formation.

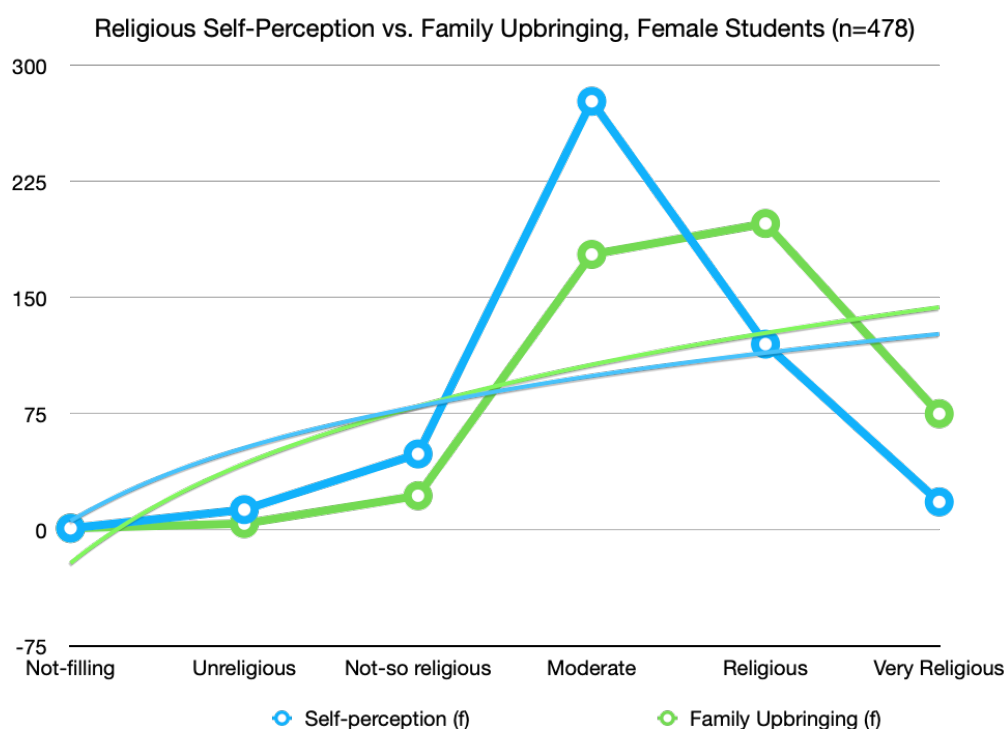


Fig. 3. Online Survey: Gen Z religious self-perception vs. their perception of family religious upbringing, among the female students

\subsection{Visual-Based Engagement}

Gen $\mathrm{Z}$ is a more visual-based generation. It is reflected in the overwhelming usage of social media outlets such as YouTube, Instagram, and TikTok. These also become the space for religious engagement. Important feature of digital technology devised through social media is the power of replication through which Gen $\mathrm{Z}$ could insert their digital subjectivity into it and become part of the larger virality culture. Following is a video example taken from TikTok, distributed in YouTube and having different versions of performers (mostly young people) and also appeared in memes and posters. The video is entitled "Buat Apa Pacaran ntar juga ujung-ujungnya putus?" ("What's the point of dating, if in the end it is broken?").

While this is an example of an instrumentalized message that emphasized the access, efficiency and maximum performance [16] and the power of digital replication, in the present case of Gen Z, it might tell us little bit more. This might be an expression of social self through which the religious message is not only mobilized and spread out through social media within the youth culture, but the social media platforms allowed the users to participate to the larger religious agenda, which in this case aligning with the massive transitory religious rhetoric of hijra, through which dateless relationship (relasi nirpacaran) is endorsed.

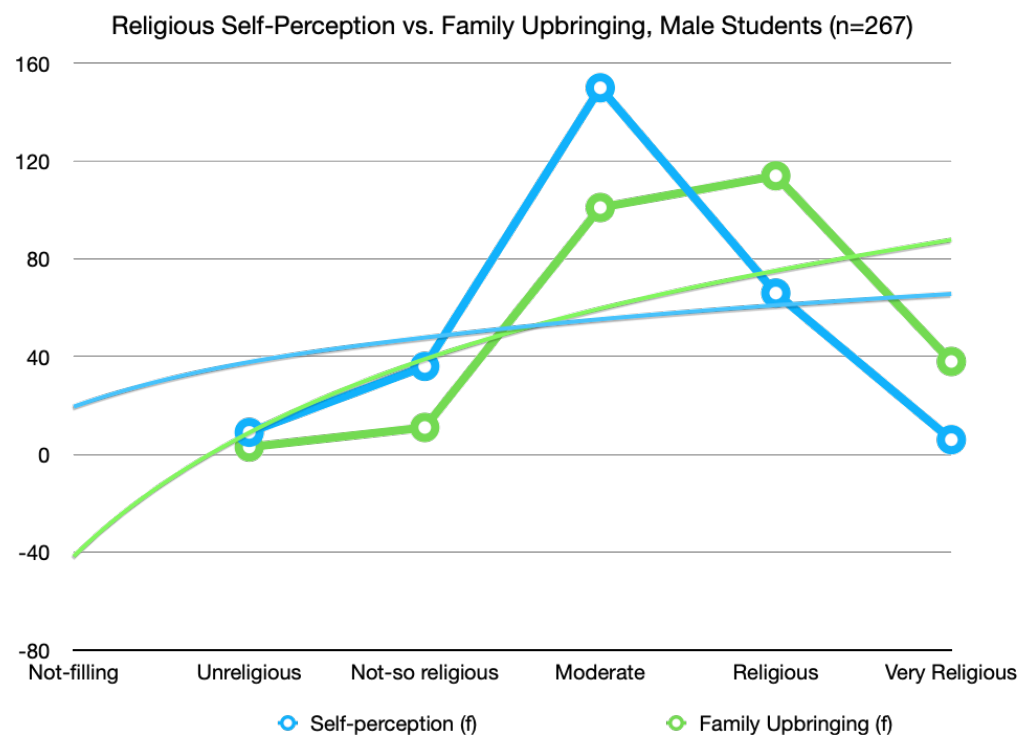

Fig. 4. Online Survey: Gen Z religious self-perception vs. their perception of family religious upbringing, among the male students 
On the other hand, social media produces dynamic social self which manifested in the interplay of the rhetoric of independent self, self-image making, and religiosity. An Instagram activist, herself a hijabi, made a caption in one of her Instagram posts "Tubuhku, otoritasku" (my body, my authority), which taken from the larger context might suggest the rhetoric of "freedom." However, when it taken together with her Islamic stylist look and the hashtag, i.e., \#xxxTinggixxxKecil, hence we found a rather complicated subtext. The authority upon her body was in relation with her style and body shaping (diet), and at the same times it also related to her Muslim position and activism in a student Muslim association, rather than entertaining of the full-fledged "feminist" outlook.

\subsection{Minority Offline, Minority Online}

Behind the curtain, religious minority groups remained the most suffering group in term of religious identity politics. In our research informants, the representations of Gen $\mathrm{Z}$ from the minority groups, i.e., Hindus, Buddhist, Confucian, and Sapta Darma, a spiritual group member (aliran kepercayaan), manifesting the regular struggles undergone by minority groups. Aliran kepercayaan is constantly portrayed by different section of religious majority as "non-religious" or non-believers (kafirs) that needs to return to the genuine religion, i.e., Islam or Christianity.

Their experiences are including, the misrepresentation of religious identity (Confucians and spiritual group members); marginal religious expression in social media, which recalled the earlier research findings, "minority offline, minority online" [5]; regenerational challenges; limited availability of youth-version of religious provision; and submissive attitude toward the dominant religious discourse, which emphasis the condition of the "spiral of silence" [15].

\section{Conclusion}

Some conclusions can be drawn from the above engagement. Gen $\mathrm{Z}$ underwent the objectification of their experience by the earlier generation and became an object of imagination of "future generation," "new powerhouse, new market," and others. They are a technological savvy generation and highly visual generation, hence expressing their religiosity through visual technology.

On the other hand, the Millennials have become new religious authority and information curator for Gen Z. They become the "bridge" between earlier generations and Gen Z, as they underwent almost similar experience, in particular digital exposure.

Some of Gen $\mathrm{Z}$ absorbed into the religious public sphericule (micro-public space) that tended to be homophilial (e.g., liqa', komsel) through which they underwent the condition of governmentality that controlled their religious discourse. However, beyond those public sphericule arrangements, Gen $\mathrm{Z}$ engages with religious doctrines devised through their experience, such as dating, religious attire, and interfaith experience. Like their Millennials sibling, Gen Z emphasized "experience" over "rational affirmation" in regard to religious precepts.

Finally, the online survey indicated that Gen Z perceived their parents were more religious than they are. This might signify the demands of the larger social space among them to explore the religious landscape.

Some recommendations are endorsed from the present undertaking. 
- Dealing with Gen $\mathrm{Z}$ is dealing with Millennials as well, as Millennials have a strategic position to become the bridge between earlier generations and Gen Z.

- Gen Z needs more space for exploring and expressing their religiosity.

- Like their Millennial siblings, Gen Z tended to emphasize "experience" over "rational affirmation" in regard to religious precepts.

- Visual culture becomes an important space to engage with Gen Z.

\section{References}

[1] Balakrishnan, J. and Griffiths, M.D. 2019. Perceived Addictiveness of Smartphone Games: A Content Analysis of Game Reviews by Players. International Journal of Mental Health and Addiction. 17, 4 (Aug. 2019), 922-934.

[2] Bamualim, C.S. et al. eds. 2018. Kaum Muda Milenial: Konservatisme, Hibriditas Identitas, dan Tantangan Radikalisme. Center for the Study of Religion and Culture, UIN Syarif Hidayatullah.

[3] Campbell, C. 2013. Toward a Sociology of Irreligion. Palgrave Macmillan.

[4] CISForm 2019. Menanam Benih di Ladang Tandus: Potret Sistem Produksi Guru Agama Islam di Indonesia. CISForm.

[5] Epafras, L.C. 2016. Religious e-Xpression among the Youths in the Indonesian Cyberspace. Jurnal Ilmu Komunikasi. 13, 1 (2016), 1-18. DOI:https://doi.org/10.24002/jik.v13i1.596.

[6] Hasan, N. 2013. The Making of Public Islam Piety, Democracy and Youth in Indonesian Politics. SUKA Press.

[7] Hasan, N. 2015. Violent Activism, Islamist Ideology, and the Conquest of Public Space among Youth in Indonesia. Youth Identities and Social Transformations in Modern Indonesia. K. Robinson, ed. Brill. 200-213.

[8] IDN Research Institute 2020. Indonesia Millennial Report 2020: Understanding Millennials' Behaviours and Demystifying Their Stereotypes. IDN Media.

[9] Kailani, N. 2011. Kepanikan Moral dan Dakwah Islam Populer: Membaca Fenomena "Rohis" di Indonesia. Analisis. 11, 1 (Jun. 2011), 1-16.

[10] Keane, J. 2013. Democracy and media decadence. Cambridge University Press.

[11] Lelono, M. et al. 2020. Toward a Theology of Engagement: a Study of Komunitas Tritunggal Mahakudus as a Field of Action. Journal of Asian Orientation in Theology. 2, 1 (Feb. 2020), 83104. DOI:https://doi.org/10.24071/jaot.2020.020104.

[12] Lipka, M. 2015. Millennials increasingly are driving growth of 'nones.' Pew Research Center.

[13] Maarif Institute for Culture and Humanity 2018. Countering Radicalization in Education, Creating Inclusive and Multicultural Schools. Technical Report \#7. Maarif Institute for Culture and Humanity.

[14] Nasrallah, E.M. 2014. None of the Above: How the Unaffiliated are Redefining Religion and Keeping Faith. FriesenPress.

[15] Noelle-Neumann, E. 1974. The Spiral of Silence: A Theory of Public Opinion. Journal of Communication. 24, 2 (Jun. 1974), 43-51.

[16] Nunes, M. 2012. Abusing the Media Viral Validity in a Republic of Spam. Transgression 2.0: media, culture, and the politics of a digital age. T. Gournelos and D.J. Gunkel, eds. Continuum. $154-168$.

[17] Ong, W.J. 1991. Orality and literacy: the technologizing of the word. Routledge.

[18] Parker, L. and Nilan, P. 2013. Adolescents in contemporary Indonesia. Routledge.

[19] Pramuadji, S. 2014. Digital behaviour in Indonesia (Media Day Nontondotcom).

[20] Sari, T.Y. 2019. Hijrah and Islamic Movement in Cyberspace: A Social Movement Study of AntiDating Movement \#IndonesiaTanpaPacaran. Universitas Gadjah Mada.

[21] Turner, V.W. 1977. The Ritual Process: Structure and Anti-Structure. Cornell University Press.

[22] Van Gennep, A. 1960. The Rites of Passage. The University of Chicago Press. 